\title{
Theoretical Analysis of Entrepreneurship Challenges and Prospects in Nigeria
}

\author{
Okezie A. Ihugba*, Alex Odii, A. C. Njoku \\ Department of Economics, Alvan Ikoku Federal College of Education, P.M.B 1032 \\ Owerri, Imo State, Nigeria \\ *E-mail address: ihugbablack@yahoo.com \\ The success of generating income for majority of rural and \\ employment highly depends on Entrepreneurship. They are the bo kbo feconomi development all
}

\section{ABSTRACT} over the world and play important role for employment, incor and soc. changes, particularly in transition economies like Nigeria. This paper is concerne with the nature the extent to which entrepreneurship in Nigeria has been developed so far, a d outlines the initiative by government and also the main current and future challenges and perspect sor the dey elopment of entrepreneurship. The study revealed that such initiatives by governm failed at ysmally due to over bearing bureaucracies, corruption, inadequate and ineficient infras facilities and maladministration. The paper concludes that entrepreneurship mi other country is an engine for job creation; innovation and diversity and Nigeria's entreprene rs h* $\quad$ g way to go before they can effectively drive changes in the economy and recommends at Government (policy makers) should genuine recognize the essence of entrepren on to ec nomic development by providing the enabling environment for private sector lo invest ent for e nomic development and also provide adequate infra-structural facilities (wate elc cit work, communications etc.).

Keywords: entrepreneurs bureaucrac orruption; economic development

1. INTRO

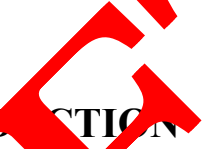

on's a $v$ generate a steady stream of business opportunities can only come ab whe its peopl ake to entrepreneurial activities. Good Entrepreneur can create a strong econ an important facet of industrial growth and development of a nation. Accora to Harper (2003) entrepreneurship is the main mechanism that creates wealth, explanatio of economic growth and development often ignore (or fail to acknowledge explicitly) the entrepreneurial forces of change and adaptation that underlie economic performance. Surprisingly, the role of entrepreneurship in economic development has attracted less professional interest than the role of other factors, such as the accumulation of physical capital, expansion of the labour force, $\mathrm{R} \& \mathrm{D}$, technological progress and education. Entrepreneurship is something we ignore at our peril. Entrepreneurship is pertinent to the analysis of how new ideas or 'recipes' for reconfiguring objects in the material and social world can be harnessed to enhance a nation's wealth. In the longer term, a country's economic progress depends on its ability to increase the value of what it produces with its resource base 
(people, land and capital). The point cannot be emphasized too strongly, however, that neither the ends to which these resources are put nor the means for achieving these ends (i.e. the set of resources and how they are used) are given or fixed. They are the result of entrepreneurial choices and are open to entrepreneurial initiative. Individual entrepreneurs and entrepreneurial teams bring to light the resources, technologies and trading opportunities that make economic development possible. Indeed, whenever entrepreneurs are the first to discover the availability and potential economic value of new resources, they are in effect bringing those resources into existence in economic terms (Kirzner 1989). Nigeria as a country has numerous business and investment potentials due to the abundant, vibrant and dynamic human and natural resarres it possesses. The performance and effectiveness of entrepreneurs in the country as a instru. of economic growth and development has long been under scrutiny. This inter scrutiny $\mathrm{h}$ been against the backdrop of the low performance and inefficiency that chac red sma business particularly in assessing its role on economic growth and development. To ing ne country's resources require the ability to identify potentially useful $/$ econ vically able fields of endeavours. Nigerians have equally made their marks in di rso 1 s such science, technology, academics, business and entertainment. Entrepreney ship activ and innovative ingenuity in Nigeria have developed enterprises in areas suct a riculture/ $o$-allied, solid minerals, transportation, information and telecom, hospita and rism business, building and construction etc. According to Anyadike, Emeh an resources notwithstanding, Nigeria is still one of the borest countries iv the world and has one of the highest rates of youth unemployment in sub-S ara Africa, nd despite its alleged strong economic growth. In respect of the above sad and lorable s uation, the government has done little to reduce the misery and frustrations of th iny. This has foisted a state of hopelessness on majority of young and old who have resorted to any means including crime to succeed in life. They resort to vices ecas y are not gainfully engaged. In other words, they are unemployed; unemployed, not ecause they lack the qualification but because the system has been crippled poitica , econo ically, socio-culturally and even religiously Anyadike, Emeh and Ukah (2,Th need for entrepreneurship development in the country today is necessitated by fau at a reneurship development is a major factor in economic growth and velopmen also the permanent cure for extreme hunger and poverty necessitated y $\mathrm{y}$. nloymen. It is in this respect this paper seeks to highlight the major challenges a prosp of entrepreneurship in the country and thus proposing some plausible strate ies that can $\mathrm{p}$. Iote effective entrepreneurship that will help develop the economy. $T$ pap is organized as follows: the first section identifies the concept of entrepreneurs. its role a economic development. The second section gives background inform of $\mathrm{N}$ a's -ntrepreneurs. The third section focuses on the relationship between entr prene $\mathrm{s}$ and dy copment and finally, conclusion and recommendation.

\section{ENTh TRENEURSHIP THEORIES}

The theory of entrepreneurial discovery is the most widely accepted conception of entrepreneurship among market-process theorists. In line with the broader research programme within which it is embedded, this approach is distinguished by its focus upon the nature of competitive processes, market disequilibria, and the role of knowledge, expectations and learning in the operation of markets, the nature and significance of entrepreneurial discovery, and the comparative effectiveness of alternative institutional frameworks for evoking entrepreneurship. According to Duru (2011) early scholars viewed entrepreneurship from 
different dimensions, they describe entrepreneurship from the perspective of functions of an entrepreneur, which include as an inventor, imitator, innovator, or more appropriately as a calculated risk taker. According to Cantillion (1932) the essence of the function of the entrepreneur is to bear risk (uncertainty). Kirzner (1997) saw entrepreneur as someone who is alert to profitable opportunities for exchange. He operates on opportunities that arise out of new technology. Schumpeter introduced the concept of innovation and power.

$\mathrm{He}$ believes that entrepreneurs bring about change through the introduction of new technological processes or products. Schumpeter argues that only certain extraordinary people have the ability to be entrepreneurs and they bring about extraordinary events. He dicoorees with Weber and other theorists of entrepreneurship that entrepreneurship is a funct on of so cultural or religious factors; rather, he believes that individuals are motivated b tavistic $\mathrm{w}$ to achieve power. He insists that this desire could occur randomly in ethnicully h ogeneo group. Knight (1921) views an entrepreneur as a calculated risk taker. $T_{1}$ e entrepro ir is an individual who is prepared to undertake risk and the reward (profit) the re on for aring uncertainty, and is an uninsurable risk. Casson (1982) recognizes that entrepr cur will have different skills from others. These skills enable the entrep eneur to ve ju gments, to co-ordinate scarce resources.

McClelland (1961) introduced the concept of need for chie ent and goal setting. He argues in his book "The Achieving society", that the dr. movards ac .ment is the basis of activity for most entrepreneurs. He used the Jew i his illustration. According to him, the Jewish child is shown from the beginning that he ha o maintain and remain on top in order to counteract the attitude of the society to him. McClell conclude, that because of this method of rearing, which the Jewish operates, thev are alth lop and strive for excellence anywhere they live.

Hagen, in his book, " The theory of soo $1 c^{t}$ arro argue that creative personality in an individual is characterized by high noed for ao evement, law, order, autonomy, and problem solving. Economic development $\mathrm{TO}_{\mathrm{H}}$, is bas ally a process of ecological change brought about by the technological a ity 0 individual concerned. He sees the entrepreneur as a reactive problem solver, $j$ su practical problems in most cases through the application of creativity at times, epreneurs are motivated by some internal forces as a duty to do something ant, before th, die.

\section{1. Who Is A Entrepreneu.}

Accon to surun (2001) the word entrepreneurship is derived from the French word "entreprende" aning to 'undertake'. To this end, an entrepreneur is someone that creates a bucinc But as a by Zimmerer and Scarborough (2006), although the creation of by ess is certainly in important facet of entrepreneurship, it is not the complete picture. The entro erson brings in overall change through innovation for the maximum social good. $\mathrm{h}$ an values remain sacred and inspire him to serve the society. He has firm belief in social bet nent and he carries out this responsibility with conviction. In this process, he accelerates personal, economic as well as human development. The entrepreneur is a visionary and an integrated man with outstanding leadership qualities. With a desire to excel, he gives top priority to Research and Development. He always works for the well-being of the society. More importantly, entrepreneurial activities encompass all fields / sectors and foster a spirit of enterprise for the welfare of mankind. 


\section{2. Entrepreneur in Nigeria}

Entrepreneurial forces are relatively strong in this country. It has become paramount in a "specially tottering economy" like Nigeria's, that her citizens, young and old alike unemployed, under-employed and even the employed take on enterprising and risk-taking characteristics in order to sustain family and self above the poverty line. Like natural traits, the average Nigerian is alert to grabbing as much as he can while he can to stay afloat (Obiajuru, 2012).

In the last decade more Nigerians have attended entrepreneurial trainings, taken courses in entrepreneurship than ever before. Virtually all young graduates have been $\quad$ or received some form of tutoring on the topic, thanks to the National Youth 9 ervice Co orientation programme. With all this in place, however, the success rate of snia $n d$ mediu enterprises has been very low; businesses have barely survived, let al $\rightarrow$ thri beyo d incubation period. Some have down-sized to the barest minimum, oth s pres or in anticipation of a better tomorrow, yet many more have been frustrat

Government regulations and policies, insecurity and a see gly edeema ce power sector haven't made it any easier. Nonetheless, some business have brok thr ough the ice to become successful amidst the apparent national gloom an onc ng appeal to be common to them all, a pregnant word with definitions flexible eno tho acc nodate key ingredients of our understanding of entrepreneurship and much m e-passion, loo $y$ defined as a strong feeling, intense emotion, compelling feeling, enthusi $\mathrm{m}$, desire, eager interest in or admiration for a proposal, cause, or activity (Obiajuru, 2012).

\section{3. Challenges to the Entrepreneur in $N$}

The challenges faced by entrepreneurs i dey countries are monumental and quite similar. The challenges are as follows:

1. Lack of Credit Facilitie Pote ial Nige entrepreneurs go through many hardships when trying to access dit their businesses. Though there is a wide range of financial institutig s that business loans, they usually charge high interest rates deterring aspiri ntreprene. For instance, major banks have pegged their lending rates to as $\mathrm{m}$. $\mathrm{h}$ a $\mathrm{o}$ deterry $\mathrm{ig}$ potential entrepreneurs who are mostly low income earners. O r obstach aced by our entrepreneurs include severe collateral conditions set by anks and other le ding institutions.

2. Corru $\mathrm{p}_{\mathrm{p}} \mathrm{Wides}$ read and all present corruption that makes the procurement of linanses, nits, oods and services from government agencies and even the payment or kes and es difficult without playing the game i.e. paying bribes and kickbacks. Government Policies: Government inconsistency is really a challenge an repreneur will have to tackle if he must succeed in Nigeria. Governance is something en. Keneurs have no control over; all entrepreneurs can do is to influence government's policy with respect to enacting favorable business laws. But he must have political clout and massive resources to be able to influence government laws. Now he may not have the political clout or financial muscle to influence government's policy so the best strategy to combating the ever changing policy of the government is to keep a keen eye on government laws and swiftly adjust your business to align with the policies.

4. Multiple Taxation: One other sensitive challenge that is encountered by majority of Nigerian entrepreneurs is multiple taxation. Although entrepreneurs in a country have 
a responsibility of funding the government through paying taxes, most of the taxes charged on entrepreneurs are not lawful and have the effect of increasing the cost of doing business. Although Nigeria's Companies Income Tax Act (CITA) has approved only 39 taxes and levies, there are over 500 various levies and taxes that are imposed by state and local government agents. These taxes are questionable and in the case where they are genuine, they are mostly duplicated and this has the effect of increasing the cost of doing business.

5. Poor State of the Country's Infrastructure: The state of Nigeria's infrastructure can be deemed to be a nightmare to both entrepreneurs and the rest of the country's n $n$. With the existing infrastructure deteriorating and in some places it is no -existent, cost of doing business has tremendously gone up. The state of the ntry's ro network makes it hard for entrepreneurs in the agricultural sector to nspo arvest d produce from farms to processing factories. According to a repor ieleas by $\mathrm{d}$ orld Bank, Nigeria's pace of socioeconomic development and groy wa oulo wh nat we can achieve. This is mostly because of the erratic supp of tricity nich has negatively affected many businesses. The outcome of ver probl bas prompted entrepreneurs to generate power through expensive vay at have il furn increased their production costs and made their products un petitiv to high prices.

6. Failure to Adapt to the Changing Business Eny ronment: Majoriy of those who venture into MSMEs (Micro, Small and Medium E erprises) do so because of their need to make money and in almost all cases, such repreneurs lack relevant and adequate information about the businesses they engage $\mathrm{In}_{\mathrm{t}}$ th event where problems arise, most of these business owners lack si problem solving skills and in the end they find it hard to survive. With the gro th introduction of GSM in 2002. Nigeri as become one of the fastest growing ICT market not only in Africa uta world de. This presents a challenge to entrepreneurs who have not embrace chno ogy, and no are now finding it hard to remain relevant in the competitive $b$ ine. For existing and potential MSMEs to survive and be relevant to must ac to the changing business environment and embrace technology.

7. Low Stan of Edu There is no gainsaying the fact that education is the key to knowle age and that it $\mathrm{p}_{\mathrm{s}} \mathrm{s}$ a strong role in forming the burgeoning entrepreneur. The wor day sangl bal village and since an intending entrepreneur must be conversant and in with ey hts around and about him, education becomes a critical factor in PT aring a

Ser arity Issu-s - When there is no guarantee of security of lives and properties, it is Iricurm run a successful venture. According to Arizona (2009), Nigeria has become a of kidnapping and resulting in incessant hostage taking, kidnapping and unjust har osment.

9. Getting venture capital to finance entrepreneurial endeavour in Nigeria is very difficult because of the political and economic instability.

10. The policies of the Nigerian government are a barrier to the success of large-scale entrepreneurial success for many Nigerians. The government is plagued by corruption and greed. The government systematically ignores laws that are already in place to promote free enterprise. 
11. The lack of enforcement of Nigerian patent laws discourages entrepreneurs from commercializing their ideas and inventions.

12. The constant political turmoil in the country greatly limits foreign investors who would be willing to provide resources for entrepreneurship in the country, which is very rich in natural resources.

13. Political and social movements strongly affect the level of entrepreneurial activity in Nigeria. Religious intolerance and ethnic warfare limit country progress in some areas of the country.

14. Female entrepreneurs in Nigeria are often underestimated and overlooke ${ }^{\prime}$ and they often hindered because of cultural barriers such as male/female role vitions th label women inherently inferior to men.

15. Entrepreneurship activity in Nigeria is primarily based on n cessity The a with which you start a business also tells how much the business wh you tarting a business solely because you want to make fast money? Is a bocaus ou wa to spend more time with friends and family members? Is it be you wan oe your own boss? If these are the major reasons for starting your usin then you may be getting it wrong, experts say. Make sure your business. arted be of the passion you have for the venture, experts say.

16. Poor planning: Experts say individuals who ave success ully managed major events are aware of the fact that success mostly come result of careful, systematic, strategic planning and hard work.

17. Poor product or service: The entrepre eur understand the needs of his customers and seek ways to meet these needs vi product or service which he offers to the market.

18. Nigeria is characteriz la sow grow $\mathrm{g}$ and active population, with sanitation life

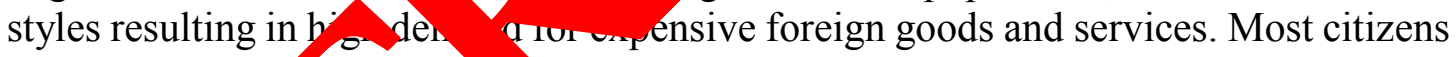
have negative at de towar nade in Nigeria goods/services, are highly religious to a point of int era in some ates. This has resulted in riots and destruction of lives and prope

\section{4. Gover ent's st Entrepreneurial and SMEs Support Initiatives}

Accordins Ogb jafor, Okonji, Olayemi, and Okolie (2011) the history of entre st ship a 15 when ne Federal Government set up several institutions and agencies to aid the dever arepreneurship and SMEs, which are listed below:

- T. Ygerian Industrial Development Bank (NIDB).

- Indastrial Development Centres

- Second Tier Securities Market

- World Bank SME I AND II Loan Schemes

- NERFUND (National Economy Reconstruction Fund)

- People's and Community Banks

- Fiscal and Monetary Policies such as:

1 Pioneer status or income tax relief act

2 Import Duty Relief 
3 Capital allowance to aid capital formation

4 Tax relief for investment in economically disadvantage local government areas.

5 Imposition of tariffs on foreign goods to ensure effective patronage of locally made goods.

6 Export promotion incentives

7 Foreign exchange facility

8 Mandatory credit allocation of between $10 \%$ and $20 \%$

- National Poverty Eradication

- Advisory Agencies

- Bank of Industry

- Micro Finance Banks

- SMIEIS (Small and Medium Industries Equity Investment Scheme

- The Nigerian Agricultural and Rural Development Bank Credit schere and sced Capital for Small Business (The sums of N200b and N7 have wen se) aside respectively under these schemes)

- The establishment of Entrepreneurship Development entres (E In six geopolitical zones of the country by the Central Bank of sige CBN, as y art of its efforts to build capacity for wealth creation and er vymen neration, as well as complement the efforts of relevant governme agencies. It ho commenced on pilot basis in three centres, namely, Kano, Onitsha and Lagos (http://allafrica.com).

However, it is regrettable that despite the hug uman and financial resources invested in these initiatives, they have abysmally failed to produ. implementation. It is either the governme politics by not backing those plans or initiatives with the adequate and timely re ase on and other resources. Thus these initiatives will be crippled and exist only in th ry and not in practice. On the other hand, the agencies saddled with the impler en on of th e,initiatives are staffed with unqualified and incompetent, officials who ha o re vant cog rate experience and integrity. These officials are mostly appointed on $t^{1}$ bas a a a filiations and willingness to manage these agencies for the benefit of their sp ors (usually government officials) to the detriment of the nation. Loans are rat to fellow oliticians, relations and friends who have no business establishments and n thing 'o with the initiatives. Such grants are seen as the individuals' share of the nat onal cake. In so cases, poor implementation is as a result of lack of relevant experience a band gon effect of corruption on the Nigeria national life.

\section{5. Eprent 0 portunities}

Nige $a$ is a co itry of over 150 million people and primarily known as an oil producer. How ary is rich in many other resources that are yet to be exploited. Sectors such as agrio re, mining, semi-precious and precious stones and other resources have taken a back seat to the roleum industry. These present opportunities for investors. According to a report published online under strategic business team and reported by Agency Reporter (2012), Martins says if you are an experienced entrepreneur or an entrepreneur with guts; then you should know that one of the best places to invest your money and build a business is in a developing terrain. Nigeria is a developing country and one of the best places to invest or build a business. They include: 


\section{Catfish and Poultry Farming}

The first of the fastest growing business opportunities in Nigeria is catfish farming. It's an emerging industry that hasn't reached its peak or full potential. The major players in this business are usually regional players. What this means in essence is that each major player in the catfish farming industry is focused only on a particular business terrain within the geographical location of the farm.

So all an entrepreneur need to do is look for a region with a growing demand that has not been covered by a major player and situate your business there. As for poultry farming, the ban imposed by the Federal Government with respect to the importation of live or froz try birds has only helped to explode the demand. When accessing any of these busin opportunities listed above, you must note three important facts.

- One, food is one of the basic necessities of man, thus making forsh farming a huge potential.

- Two, the population in Nigeria is estimated to be over 150 min an grow $\mathrm{gothat}$ entails a growing demand for food.

- Three, even if the local market with 150 million $\mathrm{Ni}$ ons gets $\mathrm{s}$ od (which I strongly doubt as this niche is still in its adolesce pha there is still a growing demand for catfish all over the world. So do you no in-de, analysis and put your money to work.

\section{6. Importation of Wears}

Importation of clothes (designer weama) into Nis another fast growing business opportunity one can tap into; but you will b the law if you engage in this business because there is a ban by the governmen on an aportation of wears. This business opportunity is listed for those who hore the ent oreneurial guts to take calculated risk (Agency Reporter, 2012).

\section{7. Sewing of Specialize}

If you don't hay entrepren 1 guts to go into the importation of wears, then you can set up a small s le te firm that will specialize in sewing uniforms. The demand for uniforms is on th merease in aria; from the crèche to the labour market, uniforms are highly in demand by it is dvisable you do your own detailed research before venturing into the business.

\section{8. IIra Wate $\%$ Transport}

nla 1 woter way transport is one of the fastest growing business opportunities in Nigeria. In fac, is is stm untapped because no modern commercial boat or ferry service system has been seen Nigeria yet. Though there are a few operators in this industry; there are no modern facilities by nng used by the developed countries. Another reason inland water way transport business proves viable is because population in states such as Lagos, Ogun State and Rivers, is rapidly on the rise thereby resulting in roads congestion. Since the roads are becoming heavily congested, the next means of transportation for these heavily populated states is water transport. With proper planning, a good management team and adequate funding, you can break into this untapped industry and carve a niche for your business. 


\section{9. Haulage and Logistics}

Haulage and logistics is another fast growing business opportunity in Nigeria. Though it is considered a risky business, you can have a breakthrough if you have a strategic business management team on ground. Good management is the key to surviving in the business of haulage and logistics.

\section{10. Out-Sourced Bus Service}

This is similar to haulage and logistics but the cargo in this case is humans. This is not about the regular road transport bus service. In this case, you are providing trasporn services to firms and corporate entities. Some corporate organizations can't aff a an in-hou transport system for their executive and staff, so this is where you come in Yo rovide $t$ cars or buses, provide the drivers and you are paid on a monthly basis or ontract $b_{a}$ for ne use of your transport services. Another area of target is schools. Mo schoo woulc ne to provide transport facilities for their students but they can't afford it and is sher you step in.

\section{11. Information and Communication Technology}

When it comes to ICT, Nigeria is lagging behind compared to th estern world. It may sound like bad news to you but to entrepreneurs and nvestors, it is good news. ICT is still an emerging trend that has not reached its peak, so a lo fopportun ties exist for both local and foreign investors.

\section{12. Cyber café}

The demand to stay connected to the res the vorld is rapidly on the increase and the cost of internet connection is sti $\mathrm{p}^{\mathrm{H}}$, when o mpared to what is obtainable in the western world, thereby making cybe afé 1 alterna ve for internet users; and an investment opportunity for entrepreney a be started either on a small, medium or large scale but preferably a lar e scale bo se size can be a competitive edge for you as customers won't like to be kept a Custom of this industry want speed and efficient service and most importantly; th wan be sure to find a vacant computer system anytime they want to surf the web wit iour having to $\mathcal{Y}$ in a queue. If you can get a good location; provide speedy internet acce and p vide complementary services; you are in for a breakthrough.

\section{13. F-Carvice}

Just the wor is going e-crazy; so also is Nigeria catching up with the trend. E-services prow on virgin business opportunity that has not fully been tapped. Under the umbre of e-services; you can find the following fast growing business opportunities: Epayment, /SMS services, web design and hosting, database management services, e-portal management, etc.

\section{14. Schools}

The need for education is on the increase and the burden to provide quality education is getting heavier for the government to bear thereby, leaving room for private and institutional investors. A lot of institutional and private investors have gone into building quality schools and providing quality education but this has not been maximized. With a population of over 150 million Nigerians, where 65 per cent are below 40, there is still untapped potential in this 
area. You can access this business opportunity from different entry levels. You can tap into this niche by providing either crèche, primary, secondary or tertiary education; but all entry levels hold strong good rewards. Carry out your own analysis before investing in any level of these opportunities.

\section{15. Seminars}

Not everyone loves being educated within the four walls of school. Some prefer street smart education or high speed learning and that is where you come in. You can set up a seminar company that organizes coaching services according to the current needs and tre the society.

\section{16. Training Centres}

Specialized training or educational centre is another fast growin vet un sped mess opportunity in Nigeria. Examples of specialized learning centro a lershi training schools, entrepreneurial centres, training centre for the gifted and ph, ally nallenged, training centre for hobbies and crafts.

\section{17. The Role of Entrepreneurship in National Dey nent}

The question of why some nations are rich and others are poor has been at the center of economic debate for over two centuries. While the post-W/NII Keynesian dominated discussion of economic development focused on a emphas zed the importance of such factors as foreign aid and government plan it is now agreed that the entrepreneur is the prime driver of economic progress (Ka to r a that the institutions that is economic agents (in lungy irepreneurs) operate in political, legal and cultural, directly influence theivity an hence economic development (Baumol, 1990; Olson, 1996). According to Sc umpe $r$ as rep ated by Ebiringa (2012), capital and output growth in an economy deperas nif of the entrepreneur deterp ano. wh capical would grow rapidly or slowly and whether the growth involves innov? where ne roducts and production techniques are developed. The difference in econor c gr rates of countries of the world is largely due to the quality of entrepreneurs in count Production factors of land, labour and capital are said to be dormant or in olent without th entrepreneur who organizes them for productive ventures. Entrepreney ave caran will continue to lead to the economic revolution that has repeatedly to rove $t c$ standard of living for people everywhere (Zimmerer and Scarb 200 Th ir role is as follows:

Economi Development: The profits made by entrepreneurs, payments for the factors of production by the entrepreneur flow as an increase into the Vational Income. Increase Gross Domestic Products, National Income etc. help in mproving the standard of living of the citizens of the country. The contributions of the SMEs in industrial sector to the Nigeria's Gross Domestic Product (GDP) are valued at about $37 \%$ there by making it the second largest contributor to the Nation's GDP after the oil sector (SMEDAN, 2009).

2 Employment Opportunities: Entrepreneurship results in the creation of small businesses. The labour intensive nature of small businesses enables them create more jobs than the big businesses. The existence of small scale businesses in the country had provided job and employment to many citizens. Small scale businesses play crucial roles in the economic development of countries (Ogundele; 2006). In 
Columbia, India, Indonesia, Kenya, Tanzania and Zambia, SMEs employ more than $50 \%$ of the workforce. Similarly they accounted for $99.9 \%$ of the 11.6 million enterprises created in the European Union. (Deloitte Touche Tohmatsu, 1995). Small Businesses created $75 \%$ of the new jobs in the USA and accounted for over $40 \%$ of GDP. Equally about $80 \%$ of Americans find their first jobs in Small businesses (World Bank, 2000). In Nigeria for instance, Small Scale Businesses (SSB) Constitutes $85 \%$ of all firms operating in the economy, and like in most other developing countries they employed the largest number of workers. A study done by the Federal Office of Statistics shows that $97 \%$ of all businesses jn-Niveria employ less than 100 employees. Looking at the definition of SMEs, seneran umbrella term for firms with less than 250 employees) it then mea that $97 \%$ all businesses in Nigeria are "small businesses". The SME sector vides, average, $50 \%$ of Nigeria's employment, and $50 \%$ of $s$ industr. vutrat. Increasing number of graduates from increasing numbe of pul and vate higher institutions who roam the streets, seeking for pla em the fey declared vacancies can avail themselves of the opportunity ay lable to a ving. Improvement in the Standard of Living through no Reduction in Rural-Urban Drifts: One of entrepreneurship in developing countries The migration of rural dwellers to cities i in congestion, high incidence of crimes, 5 Development of Local Techn development of indigenous to mitigate Rura urban drift syndrome. search of 'white-collar' jobs has resulted technological base in all countri world has been championed by native entrepreneurs; this will help in tran fer ing, much needed technology needed for the rapid transformation the coun $y$.

Conservation of $\mathrm{Fo}$ ign $\mathrm{E}$ changes: his will result from reduced importation of machineries an eq materials and payment to foreign experts. (Oghojafor, K lye, Sula n \& Okonji, 2009).

\section{CONCLUSION}

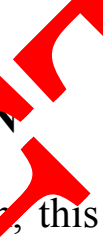

In conc or, this per has tried to unfold various issues that cluster and affect the development en. reneu ship in Nigeria. Attempts have also been made on the challenges of sust ning id crea conducive environment for Entrepreneurs to grow and prosper. So far, ey ted vidence nd arguments that highlight that Nigeria's Entrepreneurs have a long way to go sre an effectively drive changes in the economy. The entrepreneurship miracle in othe untry is an engine for job creation; innovation and diversity. The role of entreprene, ship in global business of developing countries like India is also significant. The wide range of significant contributions that entrepreneurship makes include promotion of capital formation, creation of immediate large-scale employment, promotion of balanced regional development, and effective mobilization of capital and skills. Nigerians are probably one of the most entrepreneurial people on earth. But this is not enough. For the entrepreneurs to be fully developed in the country, they need to significantly create wealth and employment opportunities thereby reducing poverty. For this to fully take place, the paper recommends that: 
- That Government (policy makers) should genuine recognize the essence of entrepreneurship to economic development.

- Government should increase its funding of financial institutions that provide on lending to entrepreneurs. Therefore such financial institutions as NBCI, NERFUND, NEXIM should be strengthened. Institutions like the National Directorate of Employment should be strengthened to provide training, capital and technical assistance to potential and practicing entrepreneurs.

- In order to positively encourage the spirit of enterprise among our young people, universities and other institutions of higher learning must be encouraged to pome more commercially focused and more entrepreneurial. They should be ecourago develop more ties with local businesses and hold more business rela ctivities

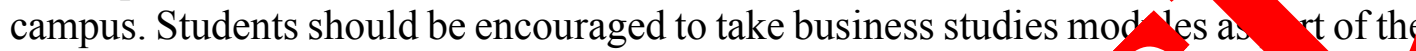
main courses. This will help develop the interest in business, nd provide bric understanding of what to expect when going into business. Th nowl a gain a will help provide students with a ready option when they gradu? ra than wa ing their time looking for the jobs that are not available. This wi ultimately $1 p t$ reduce the pool of unemployed young people in the country.

- Oil and Gas companies should partner with govern th in th iness of development of entrepreneurial skills for professionals in the economy.

- Special Industrial and Enterprises Insurance chemes should be established to absorb the risks of bad debts from new high-tech v tures. Such lebts written off should not be counted as loss but as costs of developmen

- Finally, the government should prov the enabm. nironment for private sector led investment for economic developmen $b$, riding adequate infra-structural facilities (water, electricity, road network, comr ur catio, s etc.).

\section{References} [1] Agency Reporter 20 . Opport
20 .

[2] Anyadike N,,Emeh I. E. J. Yah F. O., Universal Journal of Education and General Studies 1) $(20,088-102$.

[3] Arizona L. 2009). Jigeria: Fast Becoming Kidnappers’ Den?”, Business Day,

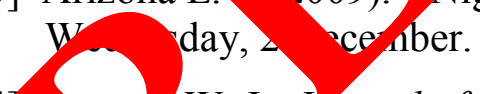

[4 aum L. J., Jjurnal of Political Economy 98 (1990) 893-921.

[5] Cà Ton R. (1931). Essai sur la Nature du Commerce en Général, London: Macmillan. First Mshed 1755.

[6] Casson M. (1982). The Entrepreneur. Oxford: Martin Robertson.

[7] Deloitte Touché Thomastor International (1995). "The European Union and SMEs", DTTI European SME Group.

[8] Duru M., Business and Management Review 1(1) 92011) 41-48.

[9] Ebiringa T. (2012). Perspectives: Entrepreneurship Development \& Growth of Enterprises in Nigeria. Entrepreneurial practice review, Volume 2 Issue 2 Winter. 
[10] Harper D. A. (2003). Foundations of Entrepreneurship and Economic Development. Published by Routledge 11 New Fetter Lane, London EC4P 4EE

[11] Ihua U., Journal of Social Science 18(3) (200) 199-207.

[12] Kasper W., Streit M. E. (1998). Institutional Economics: Social Order and Public Policy. United Kingdom: Edward Elgar Publishing.

[13] Kirzner I. M., Journal of Economic Literature 35 (1997) 60-85.

[14] Kirzner I. M. (1989). Discovery, Capitalism and Distributive Justice, Oxford: Basil Blackwell.

[15] Knight F. H. (1921). Risk, Uncertainty and Profit, Boston: Houghton Mi

[16] Leff N. A., Journal of Economic Literature 17 (1979) 46--64.

[17] McClelland D. C. (1961). The Achieving Society, Princeton: D.

[18] Obiajuru I. (2012). What the Nigerian entrepreneur needs to August 16.

[19] Oghojafor B. E. A, Okonji P. S., Olayemi O. O., Okø1 J. U. Q11). Fifty Years of

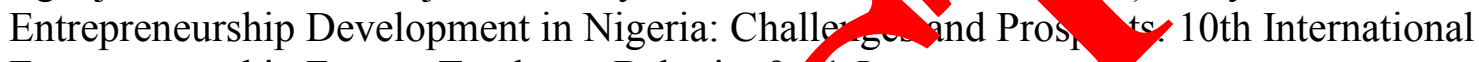
Entrepreneurship Forum, Tamkeen, Bahrain, 9 - 1 January.

[20] Oghojafor Kuye, Sulaimon Okonji, Journal of search in 1 ational Development 7(2) (2009) 9-17.

[21] Ogundele O. J. K. (2006) "Entreprenet Studies and Development in Nigeria; A Major Omission". Lagos Journal of En epre ip and Technology Vol. I. Issue I.

[22] Olson M., Journal of Econom-Derspect es 10 (1996) 3-24.

[23] Olutunla G. T. (2001). Er epren arship fo Économic Development. 27th Inaugural Lecture of the Federal Ini Anology, Akure, 26th April.

[24] Small and Mediup znterprises velopment Agency of Nigeria (2009), National Report: Lagos

[25] UNDP, (20,0,"Global p nezship for development" UNDP Annual Report 2006

[26] World nk (2 9), US World Report Washington, DC.

[27] Zimmerer W. R S arborough (2006). "Essentials Entrepreneurship and Small

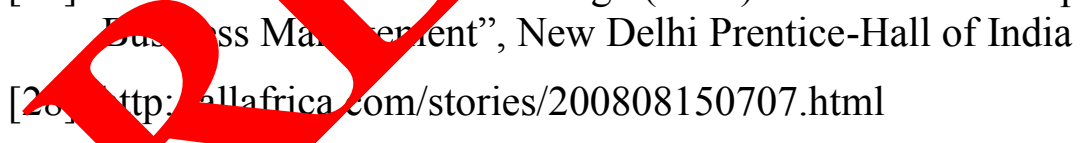

[29] h. EzineArticles.com/?expert=Peter_O_Osalor

[30] http:/ $\sim$ ww.internationalentrepreneurship.com/africa/nigeria/

[31] http://www.strategicbusinessteam.com/international-business/the-cost-and-challenges -of-doing-business-in-nigeria

[32] Tomáš Hes, Anna Poledňáková, International Letters of Social and Humanistic Sciences 2 (2013) 18-31.

[33] Mohsen Mehrara, Masoumeh Zirak, International Letters of Social and Humanistic Sciences 2 (2013) 32-38. 
[34] Taiwo Adewale Muritala, Ismail O. Fasanya, International Letters of Social and Humanistic Sciences 2 (2013) 39-50.

[35] Goran Rajović, Jelisavka Bulatović, International Letters of Social and Humanistic Sciences 4 (2013) 11-21.

[36] Petter Gottschalk, Lars Glasø, International Letters of Social and Humanistic Sciences 4 (2013) 22-34.

[37] Petter Gottschalk, International Letters of Social and Humanistic Sciences 5 (2013) 17-26.

[38] Paul Bukuluki, International Letters of Social and Humanistic Sciences 5 (2013) 27-44.

[39] Mohsen Mehrara, Maysam Musai, International Letters of Social Sciences 5 (2013) 55-62.

[40] Debiprasad Mukherjee, International Letters of Social and 6 (2013) 41-48.

[41] Goran Rajović, Jelisavka Bulatović, International Ls of al and Humanistic Sciences 6 (2013) 49-61.

[42] Mohamad Khaledian, Galavizh Khaledian, Jab Sadeghi, Reza Keyhanihekmat, International Letters of Social and Humanistic ciences 6 (2013) 62-67.

[43] Rajesh K. Yadav, Nishant Dabhade, Internationa. of Social and Humanistic Sciences 8 (2013) 77-85.

[44] Jacek Tittenbrun, International Letters os Sciat da Humanistic Sciences 11 (2013) $10-34$.

[45] Mohsen Mehrara, Hamid brish mi, Most a Boroujli, Mahan Amin, International Letters of Social and mo 11 (2013) 76-83. [45] Jacek Tittenbrun, rnationat tors of Social and Humanistic Sciences 2 (2014)
20-40.

[46] Rabi'u My'rammad Ishac ternational Letters of Social and Humanistic Sciences 3 (2014 $37-44$

[47] Bahram ami, Hy sein Meihami, International Letters of Social and Humanistic

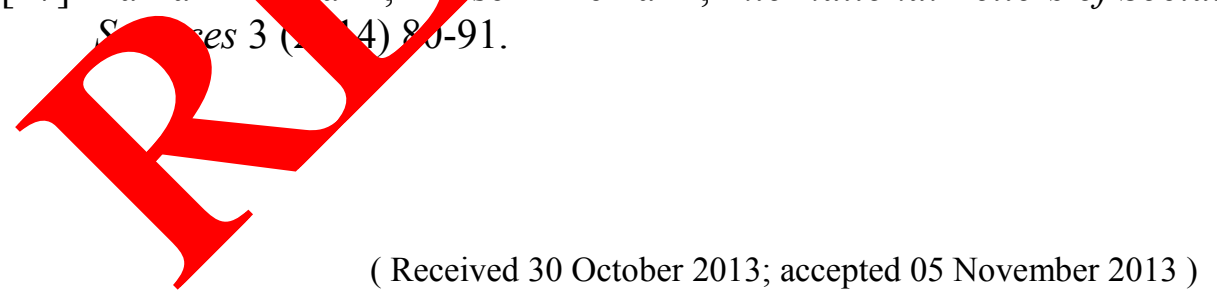

